\title{
Helping the gifted escape metaphorical entrapment
}

Jennifer Riedl Cross

College of William and Mary, jrcross@wm.edu

D. Ambrose

Tracy L. Cross

College of William and Mary, tlcross@wm.edu

Follow this and additional works at: https://scholarworks.wm.edu/educationpubs

Part of the Gifted Education Commons

\section{Recommended Citation}

Cross, Jennifer Riedl; Ambrose, D.; and Cross, Tracy L., Helping the gifted escape metaphorical entrapment (2007). Roeper Review, 29(5), 37-44.

https://scholarworks.wm.edu/educationpubs/138

This Article is brought to you for free and open access by the School of Education at W\&M ScholarWorks. It has been accepted for inclusion in School of Education Articles by an authorized administrator of W\&M ScholarWorks. For more information, please contact scholarworks@wm.edu. 
Running Head: ESCAPING METAPHORICAL ENTRAPMENT

Helping the Gifted Escape Metaphorical Entrapment

Jennifer Riedl Cross

Ball State University

Don Ambrose

Rider University

Tracy L. Cross

Ball State University

Final version accepted for publication

Cross, J. R., Ambrose, D., \& Cross, T. L. (2007). Helping the gifted escape metaphorical entrapment. Roeper Review, 29(5), 37-44. 


\begin{abstract}
Large numbers of bright people do serious, widespread harm to others while remaining absolutely certain that they are improving the world. Linguists and philosophers have revealed the powerful shaping influences of metaphor on thought. Metaphorical frameworks have inspired and confined theories of mind, research paradigms, and even conceptions of morality in the larger sociopolitical environment. This paper explores these strong metaphorical influences on thought and action with special attention to sociopolitical and moral dimensions. It reveals profound metaphorical effects on the functioning of minds as well as liberal and conservative conceptions of aspirations, selffulfillment, success, and morality. The analysis suggests the need for more attention to metaphorical analysis and the development of moral imagination in the education of the gifted.
\end{abstract}




\section{Helping the Gifted Escape Metaphorical Entrapment}

Metaphor exerts strong influences on our thinking at the implicit level (Ambrose, 1996; Anderson, 2004; Lakoff, 1993; Lakoff \& Johnson, 1980); even shaping our perception of time (Boroditsky \& Ramscar, 2002). Consequently, it may represent the most powerful and least appreciated influence on our basic assumptions about giftedness, talent, aspirations, success, and morality.

This analysis of metaphorical influence on thought draws from a broad literature base including (a) linguistic research on the ubiquity of metaphor in everyday communication and its concomitant pervasive influences on thought, (b) philosophical analyses of large-scale metaphorical worldviews that confine and shape research in academic disciplines, and (c) recent evidence of strong metaphorical influence on the nature and trajectory of polarizing, sociopolitical trends in the larger society. By gaining awareness of the implicit, large-scale, and deeply rooted metaphorical frameworks that influence the sociopolitical and economic contexts for the education of the gifted and talented, we can understand why arguments over the purposes of gifted education are so persistent and nettlesome. Educators of the gifted have the opportunity to make a profound impact on their students by developing this awareness and by challenging the metaphors that underpin common perceptions of the world around us.

By becoming aware of the metaphorical influences on thought and action in the societal context, and in gifted education, we can develop a stronger basis from which to assess the current state of the field and its preferred future direction. Theorists, researchers, and practitioners who are aware of metaphorical influence can consciously take steps to free themselves and their students from implicit conceptual entrapment. 
With their exceptional ability for complex thinking (cite?), gifted students may be exceptionally able to recognize the metaphors that guide and constrain their beliefs. Exposing the metaphors that underpin their own thinking can powerfully affect gifted students' ability to challenge those less useful conceptions.

Metaphor: Literary Construction or Feature of Knowledge Organization Metaphor has been explored for centuries in the realms of philosophy and literature. Schoolchildren are taught to recognize and produce these nonliteral constructions in early English classes. In metaphoric speech, we describe one thing in terms of another. A metaphor contains a topic and a vehicle which are linked by a common ground (Winner, 1988). We learn more about the topic by applying all the attributes of the vehicle to it. "My new car is a peach." Were this a literal statement, we would assume that the new car is a very small, soft and fuzzy fruit, but we recognize it as metaphorical. In processing the statement as a metaphor, we rapidly recognize those properties of a peach that might apply to the car: desirable, attractive, nourishing in some way to the driver. We also readily recognize the implications of the statement, "My new car is a lemon." This is the type of metaphor that has been investigated by linguists and philosophers. In the 1970s, however, the emerging science of cognitive psychology brought with it new attention to metaphor. As cognitive psychologists began to examine language for clues to the inner workings of the mind, the presence of metaphor in everyday language became apparent.

In their groundbreaking work, Metaphors We Live By, linguist and cognitive psychologist George Lakoff and philosopher Mark Johnson (1980) described the ways in which metaphors "structure how we perceive, how we think, and what we do" (p. 4). 
Rather than being simply a linguistic creation used to convey ideas, metaphor is seen as a window into the unconscious mind. Many of the words we have come to use represent foundational perceptions of the world around us. For example, there are numerous references in our language to the notion that ideas are plants: "His ideas have come to fruition," "That's a budding theory," "Mathematics has many branches," "She has a fertile imagination" (Lakoff \& Johnson, 1980, p. 47). Although we may not say it directly, many of us perceive that time is money. We know this from such common statements as

"You're wasting my time."

"How do you spend your time these days?"

"Do you have much time left?"

“He's living on borrowed time." (Lakoff \& Johnson, 1980, pp. 7-8)

The time is money metaphor underpins our understanding of the abstract concept of time and this representative speech indicates that we experience time as having properties similar to those of money. The leap from perception to behavior is not difficult to make. If time is a valuable, limited commodity, we can be frugal or generous with it; we can squander it or use it wisely. An underlying metaphor of gifted students are stars will result in different behaviors than the conception gifted students are children. If adults or their peers conceive of them as stars, gifted students will be treated with respect and honored, perhaps considered capable of accomplishments beyond their true abilities. If they are seen as children, the characteristics they share with their age peers. Either conception is likely to ignore the opposing aspects of the whole gifted student. Cognitive psychologists have learned that, by evaluating speech, we can recognize the beliefs that 
guide behavior. In this paper, we use the term metaphor to mean the belief that the nonliteral construction represents.

The Ubiquity of Metaphor and Its Influence on Cognition

Scholars from various disciplines have described the powerful influences of metaphor on thought and action. For example, linguists have revealed its shaping and confining influence on thought within linguistic and cultural frameworks (e.g., Lakoff, 1993, 1995; Lakoff \& Johnson, 1980, 1999; Whorf, 1956). Scientists and philosophers of science have demonstrated the profound influence of metaphor on the research agendas of individual scientists and on larger scientific communities (Eisenberg, 1992, May; Gruber, 1981; Haack, 1997; Harmon, 1994; Holton, 1996; Kuhn, 1993; Miller, 1996; Woodward, 1989). Cognitive scientists and theorists of human creativity have revealed the ways in which metaphor serves as thematic focal points for long-range creative work (Gruber, 1989; Osowski, 1989) while some researchers have used metaphor to organize the predominant conceptions of mind and cognition into helpful categories (Sternberg, 1990). Still others have revealed the ways in which metaphorical constructs can frame our ideological beliefs and sustain patterns of domination in society (Riedl Cross \& Cross, 2005).

Some describe the powerful shaping influences of metaphorical worldviews at the deep-rooted philosophical level (Ambrose, 1996, 1998a, 1998b, 2000; Gillespie, 1992; Overton, 1984, 1991). These worldviews strongly influence thought and behavior while framing the fundamental assumptions of scholars and laypersons alike. The mechanistic worldview encourages us to view reality as machine-like and to reduce, predict, and control phenomena in search of linear causal explanations. In contrast, the organicist 
worldview, based on the metaphor of a living organism, highlights holistic, systemic integration and teleological explanations. The contextualist worldview encourages emphasis on the unpredictable emergence of novelty and the subtle, shaping influences of contexts. Yet another worldview, formism, sheds light on interdisciplinary patterns of similarity in diverse phenomena.

Some of these metaphorical influences on thought have moral implications. For example, Ambrose (2000) revealed some ways in which the machine-like emphasis of the mechanistic metaphorical worldview provides the conceptual impetus and rationale for actions that lead to the harmful effects of social Darwinism and androcentric (male dominant) societal structures, among other difficulties. When people are viewed as atomistic, automaton-like cogs in a great global machine, their intrinsic value diminishes and they become vulnerable to the value-free decisions deriving from impersonal Darwinian socioeconomic actors.

Bowers (1993) made other moral connections with metaphor, describing how modern, Western culture promotes the assumption that language is a conduit that conveys objective information when, in reality, language is strongly metaphoric, reinforcing the shared tacit assumptions of the culture. The predominant notion of language as conduit is itself a powerful metaphor that constrains our thought, hiding the influence of metaphor on our cognition. According to Bowers, such thought constraint makes us honor the benefits of modern, technological progress while obscuring the huge costs it entails in the form of ecological damage. When through metaphor we apply the properties of one thing to another, we ignore the aspects that the metaphor does not illuminate (Lakoff \& 
Johnson, 1980). Blindness to these costs hurts our effectiveness as moral agents in the world.

We can trace the moral impact of metaphor back over the centuries. The early medieval philosopher, William of Ockham, strove to limit human speculation by insisting on the building of knowledge through observation of concrete experience and rigorous logical methods of thought to ensue from the observation (Tarnas, 1991). His admonitions for such a sanitized empiricism contributed much to the scientific method that arose in later centuries. Ultimately, his thought distilled into the philosophical injunction known as Occam's razor through which scholars are encouraged to accept the simpler of two equally plausible hypotheses. Such promotion of parsimony is all well and good up to a point. However, the philosopher Mary Midgley (1995) argued that Ockham's razor has been overgeneralized to create a mind set she calls "reductive megalomania" through which mechanistic investigators and the lay public they influence begin to view humans and the environment in which they live as nothing more than automatons.

Following Ockham by several centuries, Francis Bacon, the great pioneer of scientific method, metaphorically portrayed nature as a feminine entity that should be vigorously manipulated and controlled erotically by human rationality and technique: “...nature not only free and at large (when she is left to her course and does her work her own way) ... but much more of nature under constraint and vexed; that is to say, when by art and the hand of man she is forced out of her natural state, and squeezed and molded" (cited in Wolin, 1960/2004, p. 397). Bacon's work provided a strong basis for later 
scientific and industrial thinking, which strongly conformed to machine metaphors for natural phenomena, including the nature of the human body and mind.

More recent machine metaphors applied to humanity have continued to incite consternation over their impact on morality. In one intriguing example, cognitive scientist Joseph Weizenbaum (1995) forcefully criticized another prominent cognitive scientist, Marvin Minski, for making the statement that the human mind is nothing more than a meat machine:

In English we have two words for what he calls 'meat': meat is dead, can be burned or eaten, can be thrown away: whereas flesh is living flesh, and a certain sense of dignity is associated with it. We don't talk about eating flesh, and if we talk about burning flesh, it is a horror image. Why did he say 'meat machine' and not 'flesh machine'? It is a very deliberate choice of words that clearly testifies to a kind of disdain of the human being (p. 259).

Essentially, Weizenbaum was lamenting mechanistic thought taken to what he thought was a dehumanizing extreme, which can be a natural effect of blind entrapment within the mechanistic metaphor.

Richard Anderson's (2004) analysis of language use during the Cold War provides another example of the powerful influence of metaphor on thinking. Newspapers and public speech from the era of the Cold War between the US and Russia were filled with metaphors indicating the growing distaste for the communist threat. From Woodrow Wilson's description of Bolshevism as "poison" to the extreme right wing's frequent use of the phrase "the cancer of communism" during the 1960's, Americans came to view communism as an ill that could attack from the outside or 
internally (Gregg, 2004). The power of this metaphor shaped public perception, ignoring any possible positive aspects of communism. Did metaphor shape public opinion in the Soviet Union in the years leading up to the fall of communism, or merely reflect the changing attitudes of the time? Anderson proposed that it was the shaping influence of metaphoric speech that altered public opinion in the Soviet Union. The use of terms expressing personal superiority or subordination was much more frequent in Politburo member speeches during the authoritarian era (1966-1985) than among politicians in the years leading up to perestroika: “....as politics became more electoral, political elites used many fewer metaphors of size and of personal superiority or subordination" (p. 96). Negotiation and society are the terms that usher in the Gorbachev era. The use of these terms in public discourse preceded actual change in political institutions in the Soviet Union. Because political scientists have not found other likely causes for the shift to democratization, Anderson concluded that the changing metaphors in speech were the cause.

Such effect seems to be the objective of political strategists in contemporary U.S. politics. Linguist Deborah Tannen (2003) suggested that Republican strategist Frank Luntz is implementing this technique when he recommends to party nominees that they need only use the words constituents want to hear, not necessarily support the policies listeners will infer. In his report "Language of the $21^{\text {st }}$ Century," Luntz stated:

We should not undermine our growing strength among working-class white men (1994 set a modern-day record) in our efforts to reach out and communicate to women....I do not subscribe to the notion that we must change our substance or create a separate women's agenda. Listening to women and adapting a new 
language and a more friendly style will itself be rewarded if executed effectively and with discipline. (in Tannen, p. 30)

Luntz proposed that frequent references to children are a sure way to win women voters and this advice has been followed assiduously by George W. Bush, who, during a speech in New Hampshire during the 2004 presidential campaign, used the word child 35 times. The word child appears 23 times in Bush's 2004 State of the Union address (Cross, 2004). Using words that imply a desire to protect and nurture children evoke a response in the voting public. They hear the metaphor children are a valued object, and vote accordingly.

These examples indicate that evoked metaphors have the power to alter opinion and change behavior. Entrapment within a worldview occurs when we are unaware of its tacit influence and its powerful implications. Exposing our metaphorical beliefs enables us to challenge them.

In much the same way that Weizenbaum critiques the danger of the assumption Minski makes with his dehumanizing metaphor, George Lakoff (2002) has developed a critique of the metaphors that form the basis of contemporary U.S. politics in his book Moral Politics. In his analysis of political speech, Lakoff has determined that both conservatives and liberals in the US have as their primary metaphor that NATION IS A FAMILY. This primary metaphor is the foundation of both conservative and liberal ideology. Moral behavior derives from beliefs about family, and it is in their ideal model of family that liberals and conservatives differ. Lakoff has termed the conservative ideal the Strict Father and the liberal ideal the Nurturant Parent. What is right or moral depends on the priorities each places on certain metaphors. The Strict Father believes that "life is 
a struggle for survival" (Lakoff, 2002, p. 67). In order to survive in this difficult world, one must be able to compete successfully. This competition can be won only with strong discipline and "character." Reward for competition and punishment for a lack of obedience (a lack of self-discipline) are necessary in raising a child. Those who win the competition are rightfully successful and will be better off than others. The metaphor that has the highest priority in the Strict Father model is Moral Strength. Strength through self-discipline and self-denial is the only way to combat evil, which is seen as an internal (e.g., desires, self-indulgence) or external force that must be overcome.

The greatest concern of the Nurturant Parent is for children to be "fulfilled and happy in their lives and to become nurturant themselves" (Lakoff, 2002, p. 109). The child must be cared for, respected, openly communicated with, and protected. Children are taught through the development of a secure attachment rather than reward or punishment. The metaphor with the highest priority is Morality as Empathy. To act morally one must work to promote a sense of wellbeing in others.

The order of priorities that are the foundation of Strict Father moral reasoning is 1) Moral Strength, 2) Moral Self-Interest, and 3) Moral Nurturance. The order of priorities for Nurturant Parents is 1) Moral Nurturance, 2) Moral Self-Interest, and 3) Moral Strength. Those who place strength needs before nurturance will engage in different moral reasoning from those who place nurturance before strength. For example, when strength has a higher priority than nurturance, punishment is seen as nurturing or teaching. Strict Father moralizers view social programs as immoral because they do not reward people for being self-disciplined or punish them for being slothful. Nurturant Parents, on the other hand, see punishing drug users as immoral because nurturance is not 
given priority in a punitive approach to drug problems. They prefer addressing issues of despair over social conditions, peer pressure, and entrapment within addiction. Military spending that takes resources from social programs pits Nurturant Parents against Strict Fathers. Placing a low priority on nurturance may encourage Strict Father moralizers to see giftedness as an entity within a child, rather than as an incremental ability that requires nurturance to develop (see Dweck, Chiu \& Hong, 1995). In short, the metaphor framing our conception of family will have major consequences for social policy.

Lakoff identified these guiding metaphors through an analysis of our political system, but we can see the manifestation of these differing worldviews in individuals' support for different policies in our schools as well (Riedl Cross \& Cross, 2005). The Strict Father is likely to support practices that reward students who have followed the rules they see as important--practices that encourage self-denial and self-discipline (e.g., GPA, class rank, awards to the top performer) and punish those who have not followed these rules by employing more punitive practices (e.g., ADHD label, poor grades, discipline). The optimal Strict Father gifted program would include rewards (e.g., good grades, certificates, recognition, opportunities) for competitive exercises, with a clear hierarchy of those who have done best in the competition. On the other hand, the child's fulfillment and the development of empathy should be the primary goal of any educational program the Nurturant Parent would support. Cooperation, mutual respect, and mastery are more desirable than the rewards supported by the Strict Father.

The ideologies described are those of the central model of liberal and conservative. Most Americans hold variations of these beliefs and would not adhere to all the metaphors as Lakoff describes them, but his interpretation creates a starting point for 
us to analyze the state of affairs in education. Our system of education has developed with constraining influences of both Strict Father and Nurturant Parent ideologies and many of the disagreements we have in modern U.S. society could be resolved by a recognition of these two worldviews and the negotiations that might satisfy both. Even if these worldviews cannot be changed, an awareness of the metaphors that support moral reasoning may allow for compromise between parties with opposing views.

\section{Implications for Gifted Education}

Due to the powerful influence of metaphor on thought, it may be helpful to adjust our metaphor-bound sociocultural context and to redress injustices by using new metaphors. Moreover, helping gifted young people to develop their moral imaginations along with the generation of these new metaphors may contribute to their moral development while giving them the tools to create a more ethical world in the future.

\section{Fighting Metaphor with Metaphor}

If the ideological context for the development of the gifted and talented is sustained by limited and misleading metaphors, one way to counteract such mass selfdeception is to employ the power of metaphor for its correction. As only diamonds can cut diamonds, perhaps only insightful alternative metaphors can cut through the metaphorical entrapment that protects our self-deceit and ideological bias. Metaphor obviously has the power to trap us into habitual, often counterproductive ways of thinking and acting but it also has the power to engage the imagination and to unshackle minds. For example, Martin Luther King's extraordinary influence as a catalyst for civil rights in the face of oppression partially came from his personal charisma and magnificent oratory. But much of his impact also came from his artful use of rich 
metaphors in his speech and writing. The catalytic speech he delivered on the steps at the Lincoln Memorial in Washington D.C. on August 28th, 1963 was brief, only 1,550 words long, yet it included 45 powerful metaphors that captured the imaginations of those in attendance and the much larger television and radio audiences. These are some of King's engaging metaphors from that speech:

... a lonely island of poverty in the midst of a vast ocean of material prosperity. ... We have come to our nation's capital to cash a check. When the architects of our republic wrote the magnificent words of the Constitution and the Declaration of Independence, they were signing a promissory note to which every American was to fall heir. America has defaulted on this promissory note. . The whirlwinds of revolt will continue to shake the foundations of our nation until the bright day of justice emerges. ... Let us not seek to satisfy our thirst for freedom by drinking from the cup of bitterness and hatred. . . . we will not be satisfied until justice rolls down like waters and righteousness like a mighty stream. .. . Let us not wallow in the valley of despair. ... I have a dream that one day even the state of Mississippi, a desert state, sweltering with the heat of injustice and oppression, will be transformed into an oasis of freedom and justice.... Let freedom ring. (Extracted from Sargent, 1997, pp. 388-391) The phenomenon of metaphorical entrapment, along with the possibility of alternative metaphors freeing our minds from that entrapment as seen in Anderson's (2004) example of Russian democratization, suggests that the education of the gifted should include extensive and vigorous experiences with metaphorical thinking such as that embedded in Martin Luther King's address. Bright young people should critically 
analyze the ethical effects of the predominant metaphorical constructs in their societies, such as the mechanistic worldview or the strict father conceptions in modern Western nations. They also should explore alternative metaphors and predict the results should those alternatives come to prevail in a culture. Should organicism and the nurturing family metaphors gain considerable strength in the Western world, for example, the commonalities we share may be highlighted and our institutions may become much more nurturing and integrative. Fewer institutions would remain mechanistic containers for the impersonal treatment of atomistic, self-interested cogs in bureaucratic machine-like organizations. Finally, students may even benefit from engaging in a form of critical activism in which they see certain metaphors sustaining unjust sociopolitical or economic systems. They may employ their considerable cognitive powers to develop creative methods for making the general populace aware of their entrapment within particular metaphors while generating and communicating some compelling alternative metaphors along the lines of those generated by Martin Luther King.

\section{Using metaphor in instruction}

Laurel Richardson (2000) offered specific suggestions for challenging "worn-out" metaphors in writing. Such challenges will encourage students to think more creatively about the subjects that have been constrained by the metaphors through which they understand a concept. Richardson suggested some specific exercises:

1. In traditional social scientific writing, the metaphor for theory is that it is a "building" (structure, foundation, construction, deconstruction, framework, grand, and so on). Consider a different metaphor, such as "theory as tapestry" or "theory as an illness." Write a paragraph about "theory" using your 
metaphor. Do you "see" differently and "feel" differently about theorizing using an unusual metaphor?

2. Consider alternative sensory metaphors for "knowledge" other than the heliocentric one mentioned in the text. What happens when you rethink/resense "knowledge" as situated in voice? In touch?

3. Look at one of your papers and highlight your metaphors and images. What are you saying through metaphors that you did not realize you were saying? What are you reinscribing? Do you want to? Can you find different metaphors that change how you "see" ("feel") the material? Your relationship to it? Are your mixed metaphors pointing to confusion in yourself or to social science's glossing over of ideas? (p. 940)

Teachers of the gifted can utilize Richardson's ideas to create their own exercises, keeping in mind the students' abilities for abstract thought. One activity that challenges metaphoric thinking is not likely to have much impact on freeing students from metaphorical entrapment so metaphorical analyses should permeate instruction, thereby providing frequent reminders to recognize and challenge the metaphors that constrain the students' thinking.

We can compare instruction that reveals metaphorical influence on a student's preconceptions of a concept to instruction in moral development because both affect belief systems. Much research exists on instruction designed to move children through Kohlberg's stages of moral development (see Enright, Lapsley, Harris, \& Shawver, 1983 for a review). In order to move from stage 3 (taking a group perspective and believing it best to conform to group norms) to stage 4 (taking a societal perspective and following 
law to maintain an orderly society), a child must have moved beyond the concrete operational level of thought and have achieved formal operations. It is likely that this is also true for lessons processing complex metaphors. Children must be at an appropriate level of cognitive development to make sense of the challenges to their abstract metaphorical constructions. Carter and Ormrod (1982) found that gifted children were more likely to have achieved formal operational thought by age 13 than a nongifted sample, which averaged achievement of formal operations by age 15 . Such advanced cognitive abilities should be considered in planning instruction, due to the abstract nature of metaphor. Young gifted children may have an advantage in understanding any lessons that challenge metaphoric thinking.

Gifted students may be particularly interested in and affected by the primary metaphor Zoltán Kövecses (2005) proposed as central to American culture: life as a show or spectacle or entertainment. Citing work by Gabler (1998) and Lakoff and Turner (1989), Kövecses suggested that most aspects of American life, from shopping to politics to teaching to love, are conceived of as entertainment. This has strong implications for educators as we attempt to identify the metaphoric thinking of our students (and our own). If students conceive of life as entertainment, they may demand to be entertained in the classroom. Teachers with this conception may expect students to entertain them in their productions or they may feel the need to be entertaining. Likewise, students may feel that their performance should be spectacular and measure their success against possibly unrealistic goals, waiting to be discovered, or they may become behavioral problems in the classroom. Online education expands the opportunities to entertain, even as the teacher fades into the background as entertainer. How are all these notions altered 
if we conceive of life as war or life as compromise, as did the Hungarian participants in Niki Köves’ study (cited in Kövecses, 2005)?

If we imagine gifted young people making themselves and others more aware of the metaphors that shape their minds, we can envision some of them eventually drawing moral inspiration directly from some of the iconic sources that the neoclassical ideologues employ to bolster their own deceptive ideology. Neoclassical economists and neoconservative ideologues use Adam Smith, the eminent 18th-century economist, as their primary theoretical icon for laissez-faire economics and as justification for the stark inequalities their ideology creates. Smith generated the clever metaphor of an invisible hand manipulating the marketplace, ensuring that the countless self-centered decisions of rational individuals would meld together en-masse into a dynamic system of vigorous economic transactions. The invisible hand supposedly would turn millions of selfish individual decisions toward the market-driven betterment of all. Another influential metaphor, the trickle-down economics of the Reagan era, was based largely on Smith's economic principles (Breit \& Ransom, 1998).

It is, however, much less well known that Adam Smith was not just an economist but also a philosopher who warned that the free-market dynamics exemplified by his invisible hand metaphor would create unacceptable inequality and injustice unless mollified by regulatory practices. Fleischaker (2004) pointed out that Smith wasn't proclaiming a universal rule in the form of his metaphorical invisible hand. Unfortunately, that's how it has been construed by generations of neoclassical economists and the ideologues who follow them. In so doing, they provide a clear example of an iconic metaphor overgeneralized to the detriment of large numbers of deprived people. 
In keeping with the notion that alternative metaphors may be effective tools for combating predominant harmful metaphors, we can imagine gifted youth developing metaphors to compete with Smith's overgeneralized invisible hand. The leading political theorist Sheldon Wolin (1960/2004) provided such an alternative while arguing against the pernicious power of economic globalization. The following unflattering historical metaphor exemplifies his disdain for the reckless dynamics of free markets run amok; A contemporary economy of powerful multinational corporations resembles nothing so much as the warring city-states of sixteenth-century Italy. Corporate executives, financial speculators, junk bond wizards, and merger experts are the condottieri, the Medici, the suave popes of our time. (pp. 564)

By metaphorically portraying modern corporations as corrupt medieval fiefdoms, Wolin highlighted their regressive nature in opposition to their futuristic, progressive, cuttingedge portrayal in many financial magazines and other media outlets. Other accepted metaphors that dominate public policy could benefit from a similar reanalysis (e.g., Lakoff”s [2002] example of "The Moral Order is the Natural Order": God over people, people over nature, adults over children, and men over women).

\section{Development of the Moral Imagination through Metaphorical Thought}

Influential philosophers have stressed the importance of imagination in moral thought and behavior. For example, Kant (1988) and Hare (1963) argued that moral behavior requires the willingness and ability to imagine ourselves on the receiving end of an action we are contemplating. These arguments imply that the actions of wicked people derive at least partially from their lack of imagination. 
Rawls (1971) specified a thought experiment in which a group of ahistorical individuals comes together to agree on the rules for a new community for them and their progeny. These individuals are under a veil of ignorance about their own status and financial prospects in this new society, so they draw up rules that guarantee a fruitful blend of individual freedom and justice for the deprived. The latter derives from their fear of falling into poverty.

Adam Smith also argued that the imagination is important for moral judgment and that we must imagine ourselves into the lives of others. He promoted the development of moral imagination through the engagement of emotion (Fleischaker, 2004) instead of through the direct teaching of moral truths. As in the example of Martin Luther King, the use of metaphors that reveal injustice by enabling the listener or reader to empathize is effective because it engages our emotions. It is one thing to argue against injustice with tables, graphs and commandments yet quite another to feel viscerally the "heat of injustice and oppression" or to envision "an oasis of freedom and justice." Gifted young people should engage in moral imagination to build bridges over the empathy gulfs that currently plague our culture.

\section{Metaphorical Selection of Exemplars for Giftedness and Talent}

Another aspect of the moral imagination can derive from the nature of the exemplars we provide for the development of high ability. Metaphor can shape the ideals we hold for optimal human achievement and consequently the choice of exemplars. Ambrose (2002) argued that the ethical development of gifted young people depends somewhat on the exemplars we choose as motivators of their future achievement. While educators can have some influence through choice of exemplars, the societal context that 
permeates the lives of children arguably has much more influence due to the ubiquity of media messages (e.g., life as entertainment). The metaphors that dominate the sociopolitical and economic systems of a society will play a large part in the selection of exemplars for giftedness and talent. These exemplars may or may not be used to motivate students in programs for the gifted but they will be prevalent in the national spotlight.

Moreover, the choice of exemplars is driven by sociopolitical ideology because the concept of merit is underdefined (Sen, 2000) and depends on our definition of a good society. If a good society, or more appropriately the preferred society, is one that unreservedly trusts the metaphor of Adam Smith's invisible hand, it will display that trust by embracing laissez-faire, neoclassical economics, which promotes extreme versions of “economic freedom.” Such an ideological system encourages vigorous, creative individual talent maximization while rendering little or no judgment on the ethical effects of that talent when it manifests in the world. The only significant checks and balances on individual behavior in a laissez-faire society come from the legal system (Wolin, 1960/2004); however, unethical creative individuals tend to find ways to avoid or subvert legal controls by lobbying government legislators who oversee the creation of law (Hacker, 2005). Within a laissez-faire, value-free ideological context, the exemplars of giftedness and talent can be benevolent but they are more likely to be aggressive, often ruthless, insatiably materialistic, self-obsessed, ego-driven leaders of industry and government. When the media lauds the work of modern robber barons who build massive corporate structures on the backs of exploited foreign sweatshop workers while shedding middle class workers and mutilating the environment at home, Adam Smith's creative, productive metaphorical invisible hand has curled itself into an iron fist. 
Intelligent educators and gifted young people can work to correct the dominance of ideological metaphors turned pernicious. They can look for compelling metaphors that have the power to compete with the currently dominant metaphors and use these new constructs to enhance their own reflective capacities while attempting to awaken the minds of others. We can hope that frequent practice with such metaphorical interpretation might encourage them to become influential champions of ethics in their adult lives.

Here is a specific example of the metaphor wars educators of the gifted can promote. First, students can analyze the strengths and weaknesses of Adam Smith's invisible-hand metaphor, along with its tendency to curl into an iron fist in a laissez-faire society blind to its own ideology. Second, they can look for possible competing metaphors and analyze their strengths and weaknesses as well as the ways in which they would alter the selection of exemplars for giftedness and talent.

One alternative metaphor comes from the work of McMurtry (1999), a philosopher who employed an insightful medical metaphor derived from cancer research to show how informed democratic consent may be eroding in today's world. One of several characteristics of cancer is its deception of the immune system so that its presence is not clearly perceived and it can harm the body without retaliation. Suggesting that the media is the immune system of society because it has the capacity to warn us about pathogenic sociopolitical and economic trends, McMurtry claimed that concentration of media ownership in the hands of a few immensely powerful conservative people has compromised our society's immune system. It renders invisible the spreading dominance of runaway, laissez-faire capitalist ideology, which is analogous to cancer because healthy economic growth processes have spun out of control. The national regulatory 
checks and balances that kept capitalism a positive force have eroded due to globalization.

After the cancer metaphor reveals the danger of Smith's unguided invisible hand, another more positive metaphor can reveal the possibilities of a society in which the primary exemplars of giftedness and talent are impressive altruists and selfless champions of justice. For example, Capra's (1996) highlighting of the integrative, organic nature of scientific phenomena, and of nature itself, can inspire integrative, organic metaphors for human societies. These conceptions are consistent with Monroe's (1996) discoveries about the world perspectives of heroic altruists: those who risk their own lives to save others. Such people view themselves as tightly integrated into the whole of humankind as cells are into a body. This stands in stark contrast with the atomistic perspectives of egocentric individualists who see other human beings primarily as objects for exploitation. If gifted young people, and possibly even the societies in which they live, manage to replace the invisible hand/iron fist metaphor with the organic nature metaphor, the exemplars of giftedness and talent can change. Now, privileged relational altruists (see Ambrose, 2003) will receive magnification in the media and in the education system. Here are some examples:

1. Physicians who could enrich themselves by serving wealthy clients in posh suburban clinics instead volunteer for non-lucrative, often dangerous service through the international medical humanitarian organization Doctors Without Borders (Leyton, 1998). In so doing, they provide emergency aid to deprived people suffering from the afflictions of epidemics, armed conflicts, natural and human-made disasters, and exclusion from health care in many nations around the world. Their strong, organic sense 
of connectedness with those in plight encourages them to forego significant personal gain for the betterment of humanity.

2. Aung San Suu Kyi, the daughter of a hero who led Burma's fight for freedom from British imperial rule returned from a comfortable life in Europe to lead a prodemocracy movement against the extremely oppressive regime in her home country. Making considerable headway in her dangerous uphill struggle, she earned the Nobel Peace Prize in 1991 (Victor, 1998).

Deprived relational altruists (see Ambrose, 2003) also garner more attention when the organic metaphor prevails. For example, the activist Cesar Chavez raised considerable awareness about the plight of migrant farm workers who were being exploited by the owners of large California farms (Griswold del Castillo \& Garcia, 1997). His family lost their small Arizona farm when he was 10 years old. After that, he experienced the life of the migrant worker, which entailed long hours of hard, menial work, and crushing poverty. Ultimately, he quit school to help support the family. His experiences prompted him to lead the activists' fight against exploitation and injustice.

It may sound incongruous that somewhat intangible and fuzzy metaphors can generate massive changes in thought and action. However, if we need convincing about the power of metaphor as an ideological tool, or as a tool to counter ideological dominance, we need only look to the examples set by Adam Smith's oft-invoked invisible hand, or by Martin Luther King's powerful use of metaphor as a catalytic force for human rights reform. Lakoff's analysis of conservative and liberal moral reasoning through metaphor may make it possible to achieve compromise in our contemporary dichotomous society. Metaphorical analyses can provide interesting ways for students to 
envision a new world: one in which priorities shift and ethics comes to the fore. The same is true for educators of the gifted, who can benefit from a metaphorical analysis of the beliefs underpinning their educational practice. Our education system would be quite different if it focused less on a mechanistic, reductionist, Strict Father metaphor, and somewhat more on an organicist, holistic, Nurturant Parent one. The valuable reductionistic methods of science may have been applied in places it does not fit within our education system, neglecting our much larger, more interdependent world. Correcting this overgeneralization begins with a recognition of the metaphors on which education is built. 


\section{References}

Ambrose, D. (1996). Unifying theories of creativity: Metaphorical thought and the unification process. New Ideas in Psychology, 14, 257-267.

Ambrose, D. (1998a). Comprehensiveness of conceptual foundations for gifted education: A world-view analysis. Journal for the Education of the Gifted, 21, $452-470$.

Ambrose, D. (1998b). A model for clarification and expansion of conceptual foundations. Gifted Child Quarterly, 42, 77-86.

Ambrose, D. (2000). World-view entrapment: Moral-ethical implications for gifted education. Journal for the Education of the Gifted, 23, 159-186.

Ambrose, D. (2002). Socioeconomic stratification and its influences on talent development: Some interdisciplinary perspectives. Gifted Child Quarterly, 46(3), 170-180.

Ambrose, D. (2003). Barriers to aspiration development and self-fulfillment: Interdisciplinary insights for talent discovery. Gifted Child Quarterly, 47(4), 282294.

Anderson, R. D., Jr. (2004). The causal power of metaphor: Cueing democratic identities in Russia and beyond. In F. A. Beer \& C. De Landtsheer (Eds.), Metaphorical world politics (pp. 91-108). East Lansing, MI: Michigan State University Press.

Boroditsky, L. \& Ramscar, M. (2002). The roles of body and mind in abstract thought. Psychological Science, 13(2), 185-189.

Bowers, C. A. (1993). Critical essays on education, modernity, and the recovery of the ecological imperative. New York: Teachers College Press. 
Breit, W., \& Ransom, R. L. (1998). The academic scribblers (Vol. 3rd). Princeton, NJ: Princeton University Press.

Capra, F. (1996). The web of life: a new scientific understanding of living systems. New York: Anchor Books.

Carter, K., \& Ormrod, J. (1982). Acquisition of formal operations by intellectually gifted children. Gifted Child Quarterly, 26, 110-114.

Cross, J. R. (2004). Political Speech and Politician's Beliefs. Unpublished manuscript.

Dweck, C. S., Chiu, C-Y., Hong, Y-Y. (1995). Implicit theories and their role in judgments and reactions: A word from two perspectives. Psychological Inquiry, 6, 267-286.

Eisenberg, A. (1992, May). Metaphor in the language of science. Scientific American, $266,144$.

Enright, R. D., Lapsley, D. K., Harris, D. J., \& Shawver, D. J. (1983). Moral development interventions in early adolescence. Theory into Practice, 22(2), 134144.

Fleischacker, S. (2004). On Adam Smith's Wealth of Nations: A philosophical companion. Princeton, NJ: Princeton University Press.

Gabler, N. (1998). Life: The movie: How entertainment conquered reality. New York: Vintage Books.

Gillespie, D. (1992). The mind's we: Contextualism in cognitive psychology. Carbondale, IL: Southern Illinois University Press. 
Gregg, R. B. (2004). Embodied meaning in American public discourse during the Cold War. In F. A. Beer \& C. De Landtsheer (Eds.), Metaphorical world politics (pp. 59-73). East Lansing, MI: Michigan State University Press.

Griswold del Castillo, R, \& Garcia, R. A. (1997). Cesar Chavez: A triumph of spirit. Norman, OK: University of Oklahoma Press.

Gruber, H. E. (1981). Darwin on man: A psychological study of scientific creativity (2nd ed.). Chicago: University of Chicago Press.

Gruber, H. E. (1989). The evolving systems approach to creative work. In D. B. Wallace \& H. E. Gruber (Eds.), Creative People at Work (pp. 3-24). New York: Oxford University Press.

Haack, S. (1997). The puzzle of "scientific method". Revue Internationale de Philosophie, 51(202), 495-505.

Hare, R. M. (1963). The language of morals. Oxford, UK: Oxford University Press.

Harmon, J. E. (1994). The uses of metaphor in citation classics from the scientific literature. Technical Communication Quarterly, 3(2), 179-194.

Holton, G. (1996). On the art of scientific imagination. Daedalus, 125, 183-208.

Kövecses, Z. (2005). Metaphor in culture: Universality and variation. Cambridge: Cambridge University Press.

Kant, I. (1988). Critique of judgment (J. C. Meredith., Trans.). Oxford, UK: Clarendon.

Kuhn, T. S. (1993). Metaphor in science. In A. Ortony (Ed.), Metaphor and thought (pp. 533-542). New York: Cambridge University Press.

Lakoff, G. (1993). The contemporary theory of metaphor. In A. Ortony (Ed.), Metaphor and thought (2nd ed., pp. 202-251). New York: Cambridge University Press. 
Lakoff, G. (1995). Embodied minds and meanings. In P. Baumgartner \& S. Payr (Eds.), Speaking minds (pp. 115-129). Princeton, NJ: Princeton University Press.

Lakoff, G. (2002). Moral politics: How liberals and conservatives think. Chicago: The University of Chicago Press.

Lakoff, G., \& Johnson, M. (1980). Metaphors we live by. Chicago, IL: University of Chicago Press.

Lakoff, G., \& Johnson, M. (1999). Philosophy in the flesh: The embodied mind and its challenge to Western thought. New York: Basic Books.

Lakoff, G., \& Turner, M. (1989). More than cool reason: Afield guide to poetic metaphor. Chicago: University of Chicago Press.

McMurtry, J. (1999). The cancer stage of capitalism. London: Pluto Press.

Midgley, M. (1995). Reductive megalomania. In J. Cornwell (Ed.), Nature's imagination: The frontiers of scientific vision (pp. 132-147). Oxford, UK: Oxford University Press.

Miller, A. I. (1996). Insights of genius: Imagery and creativity in science and art. New York: Springer-Verlag.

Monroe, K. R. (1996). The heart of altruism. Princeton, NJ: Princeton University Press. Osowski, J. V. (1989). Ensembles of metaphor in the psychology of William James. In D. B. Wallace \& H. E. Gruber (Eds.), Creative people at work (pp. 126-145). New York: Oxford University Press.

Overton, W. F. (1984). Worldviews and their influence on psychological thoughts and research: Khun-Lakatos-Laudan. In H. W. Reese (Ed.), Advances in child development and behavior (Vol. 18, pp. 91-226). New York: Academic Press. 
Overton, W. F. (1991). Metaphor, recursive systems, and paradox in science and developmental theory. In H. W. Reese (Ed.), Advances in child development and behavior (Vol. 23, pp. 59-71). New York: Academic Press.

Rawls, J. (1971). A theory of justice. Cambridge, MA: Belknap Press.

Richardson, L. (2000). Writing: A method of inquiry. In N. K. Denzin \& Y. S. Lincoln (Eds.) Handbook of qualitative research. $2^{\text {nd }}$ ed. (pp. 923-948). Thousand Oaks, CA: Sage.

Riedl Cross, J., \& Cross, T. L. (2005). Social dominance, moral politics and gifted education. Roeper Review.

Sargent, L. T. (Ed.). (1997). Political thought in the United States: A documentary history. New York: New York University Press.

Sen, A. (2000). Merit and justice. In K. Arrow, S. Bowles \& S. Durlauf (Eds.), Meritocracy and economic inequality (pp. 5-16). Princeton, NJ: Princeton University Press.

Sternberg, R. J. (1990). Metaphors of mind: Conceptions of the nature of intelligence. New York: Cambridge University Press.

Tannen, D. (2003). Let them eat words: Linguistic lessons from Republican master strategist Frank Luntz. The American Prospect, 8(14), 29-31.

Tarnas, R. (1991). The passion of the western mind. New York: Ballantine.

Victor, B. (1998). The lady: Aung San Suu Kyi, Nobel laureate and Burma's prisoner. New York: Faber \& Faber. 
Weizenbaum, J. (1995). The myth of the last metaphor. In P. B. S. Payr (Ed.), Speaking minds: Interviews with twenty cognitive scientists (pp. 249-264). Princeton, NJ: Princeton University Press.

Whorf, B. L. (1956). Language, thought, and reality. Edited by J. B. Carroll. Cambridge, MA: MIT Press.

Winner, E. (1988). The point of words: Children's understanding of metaphor and irony. Cambridge, MA: Harvard University Press.

Wolin, S. (1960/2004). Politics and vision: Continuity and innovation in Western political thought (Rev. ed.). Princeton, NJ: Princeton University Press.

Woodward, C. E. (1989). Art and elegance in the synthesis of organic compounds: Robert Burns Woodward. In D. B. Wallace \& H. E. Gruber (Eds.), Creative people at work (pp. 227-253). New York: Oxford University Press. 
Author Note: Portions of this paper were presented at the November, 2005 meeting of the National Association for the Gifted, Louisville, Kentucky.

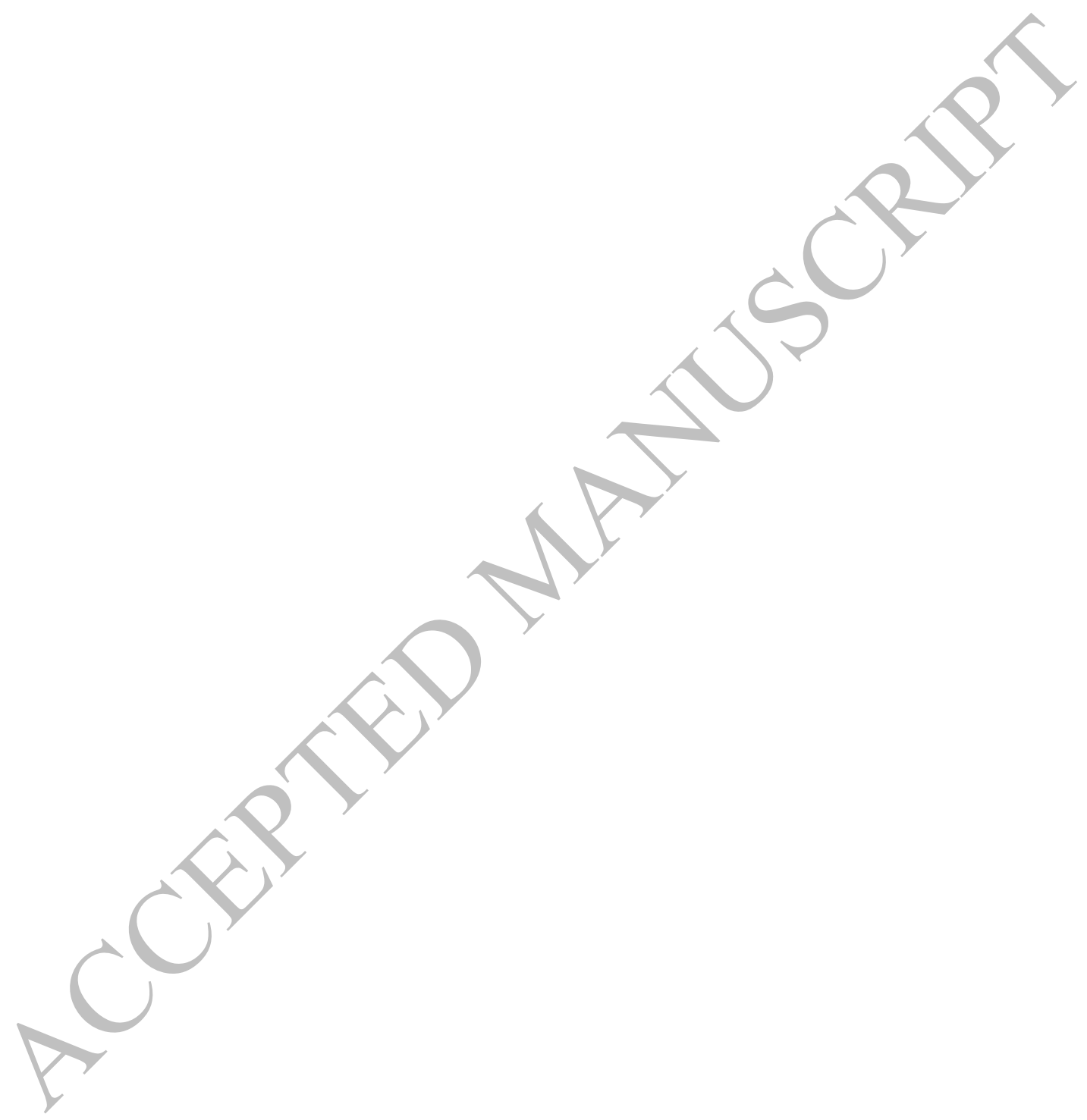

